\title{
Evidence for protracted and lecithotrophic larval development in the yeti crab Kiwa tyleri from hydrothermal vents of the East Scotia Ridge, Southern Ocean
}

\author{
Sven Thatje ${ }^{1, *}$, Kathryn E. Smith ${ }^{1,2}$, Leigh Marsh ${ }^{1}$, Paul A. Tyler ${ }^{1}$ \\ ${ }^{1}$ Ocean and Earth Science, University of Southampton, European Way, Southampton, SO14 3ZH, UK \\ ${ }^{2}$ Present address: Department of Biological Sciences, Florida Institute of Technology, 150 West University Boulevard, \\ Melbourne, FL 32901, USA
}

\begin{abstract}
The deep-sea squat lobster Kiwa tyleri (also known as yeti crab) is the dominant macroinvertebrate inhabiting hydrothermal vents on the northern and southern segments of the East Scotia Ridge in the Southern Ocean. Here, we describe the first zoeal stage of the species which is morphologically advanced - and provide evidence for its lecithotrophy in development. This morphologically advanced stage at hatching suggests that dispersal potential during early ontogeny may be limited. Adults of $K$. tyleri typically inhabit a warm-eurythermal, and spatially defined, temperature envelope of vent chimneys. In contrast, ovigerous females with late embryos are found away from these temperatures, off the vent site. This implies that at least part of embryogenesis takes place away from the chemosynthetic environment. Larvae are released into the cold waters of the Southern Ocean that are known to pose physiological limits on the survival of reptant decapods. Larval lecithotrophy may aid long developmental periods under these conditions and facilitate development independent of pronounced seasonality in primary production. It remains uncertain, however, how population connectivity between distant vent sites may be achieved.
\end{abstract}

KEY WORDS: Anomura $\cdot$ Endotrophy $\cdot$ Cold adaptation $\cdot$ Deep sea $\cdot$ Dispersal $\cdot$ Magnesium regulation $\cdot$ Embryology $\cdot$ Kiwaidae $\cdot$ Squat lobsters

\section{INTRODUCTION}

The Kiwaidae is a family of enigmatic squat lobsters that are associated with deep-sea chemosynthetic ecosystems (Macpherson et al. 2005, Thurber et al. 2011). The Southern Ocean representative of the family, Kiwa tyleri (Thatje et al. 2015), is the third known species of this family, and has been reported from 2 vent fields (E2 and E9, Rogers et al. 2012) situated on the northern and southern segments of the East Scotia Ridge (ESR). While aggregations have been observed for some Kiwaidae (Thurber et al. 2011) and Munidopsidae (Tokeshi

\footnotetext{
*Corresponding author: svth@noc.soton.ac.uk
}

2011), K. tyleri is found in exceptionally high abundances reaching 700 ind. $\mathrm{m}^{-2}$ at both sites (Marsh et al. 2012). Previous phylogeographic work has indicated that the Kiwaidae may have radiated into the Southern Ocean from a Pacific origin, probably through the deep-water connection of the Drake Passage some 30 million years ago (Ma) (Roterman et al. 2013). In this scenario, the Kiwaidae would have entered the Southern Ocean prior to the geographic and physiological isolation of this water body (Crame 1999). The process of Antarctic cooling began during the late Eocene, approximately $55 \mathrm{Ma}$, but the cold-water environment typical of the South-

() The authors 2015. Open Access under Creative Commons by Attribution Licence. Use, distribution and reproduction are unrestricted. Authors and original publication must be credited. 
ern Ocean today was likely not characterised until a final cooling step lasting until about 14 Ma (Clarke 1990, Zachos et al. 2001, Shevenell et al. 2004). These large-scale geo-climatic considerations are important when assessing the evolution and radiation of Southern Ocean fauna and have been subject to debate on many occasions (Clarke 1993, Crame 1999). The origins and antiquity of Southern Ocean biota, in many cases, may pre-date the Antarctic cooling event. The subsequent isolation, and evolution in situ, likely contributed to the great diversity of organisms and peculiar life forms that characterise faunal assemblages found there today (Clarke \& Johnston 2003, Aronson et al. 2007, Thatje 2012, and references therein).

The extant Southern Ocean decapod crustacean fauna is considered highly impoverished when compared with other marine environments (Gorny 1999, Aronson et al. 2007). It is characterised by about a dozen caridean shrimp species, and of the reptant decapods, only the Lithodidae family (king crabs) appears abundant, with at least a dozen species found (Gorny 1999, Thatje \& Arntz 2004, Smith et al. 2012). The general lack of reptant decapods has been attributed to their failure to synchronise their early life history with conditions of low temperature and pronounced seasonality in primary production (Clarke 1990, Thatje et al. 2003). Further, most crabs seem to lack the ability to down-regulate $\mathrm{Mg}^{2+}$ contents in their haemolymph below that of seawater, which at polar temperatures leads to a narcotic state resulting in death (Frederich et al. 2001). The success of the anomuran lithodid crabs in most parts of the Southern Ocean where temperatures do not drop below approximately $0.5^{\circ} \mathrm{C}$ (Thatje et al. 2008, Hall \& Thatje 2011) has been attributed to hypometabolism and the optimisation of all life-history stages to low temperature. Optimisation includes larval lecithotrophy and slow development (Anger et al. 2003, Kattner et al. 2003, Thatje et al. 2005, Thatje \& Mestre 2010).

The anomuran squat lobster $K$. tyleri is an ideal species to test hypotheses questioning physiological constraints on Antarctic fauna. Because the more advanced juvenile and adult stages live within the warm-water thermal envelope prevailing at vent chimneys (Marsh et al. 2012, 2015), they are not subjected to the thermal constraint of cold polar seas. However, recent work (Marsh et al. 2015) has demonstrated that ovigerous females leave vents to brood and release offspring into cold Southern Ocean waters $\left(0.0\right.$ and $-1.3^{\circ} \mathrm{C}$ at E2 and E9 vent sites, respectively; see Rogers et al. 2012).
Here, we describe the morphologically advanced first larval (zoeal) stage of $K$. tyleri. We provide evidence for its full lecithotrophy in development, and critically discuss this reproductive trait with regard to physiological and ecological constraints on the species to disperse. The results raise the question of whether extant populations of $K$. tyleri are capable of maintaining long-distance population connectivity.

\section{MATERIALS AND METHODS}

\section{Sampling of females and larvae}

The material used in this investigation was obtained from the E9 vent field, located in segment E9 of the ESR, during the RRS 'James Cook' research cruise 42 in February 2010 (Rogers et al. 2012). Specimens of Kiwa tyleri were obtained from a biological sampling dive (Dive 144, 2 February 2010; $\left.60^{\circ} 02.82^{\prime} \mathrm{S}, 29^{\circ} 58.72^{\prime} \mathrm{W}\right)$ at about $2400 \mathrm{~m}$ water depth, using the remotely operated vehicle (ROV) 'Isis'. Specimens were collected away from the large aggregations associated with the vent chimneys using the ROV suction sampler and stored in closable bio-boxes (Marsh et al. 2012, 2015). The ambient water temperature at this latitude was approximately $-1.3^{\circ} \mathrm{C}$. For further description of the vent field, chemical and biological characteristics, please consult Rogers et al. (2012) and Marsh et al. (2012, 2015).

Once on board RRS 'James Cook', ovigerous females were identified and kept under temperaturecontrolled aquarium conditions, either at $1 \mathrm{~atm}$ or at in situ pressure (240 atm) using an IPOCAMP pressurised experimental tank system (for a description, see Ravaux et al. 2003). Incubation temperature was $5^{\circ} \mathrm{C}$ for the purpose of physiological experiments unrelated to the present study. Larvae used here were found hatched on the morning following sampling, and no morphological difference in larvae hatched at atmospheric or in situ pressure was detected. Larvae did not demonstrate any active swimming behaviour, but a continuous and consistent heartbeat was present.

\section{Sampling for elemental analyses}

Samples for determinations of dry weight (DW) and elemental composition ( $\mathrm{C}$, carbon; $\mathrm{N}$, nitrogen; $\mathrm{C}: \mathrm{N}$ ratio) with $\mathrm{n}=5$ replicates each (1 individual per replicate) were taken on the day of hatching. A comparison of intraspecific variability of larval energy con- 
tents at hatching was carried out using larvae from 5 females. Weight measurements were taken with a Micro Balance (Sartorius ME5, accurate to $1 \mu \mathrm{g}$ ). Techniques and equipment used for obtaining $\mathrm{C}$ and $\mathrm{N}$ content of larvae were the same as described by Anger \& Harms (1990): short rinsing in distilled water, blotting on lint-free Kleenex paper for optical use, freezing at $-80^{\circ} \mathrm{C}$, vacuum drying at $<10^{-2}$ mbar, weighing and combusting at $1020^{\circ} \mathrm{C}$ in a Fison (Carlo Erba) 1108 Elemental Analyser. The elemental analyser was calibrated using chitin as a standard (\% $\mathrm{C}=$ $44.71 ; \% \mathrm{~N}=6.79$ ). $\mathrm{C}$ and $\mathrm{N}$ percentages were determined during analysis, and the $\mathrm{C}: \mathrm{N}$ ratio was calculated.
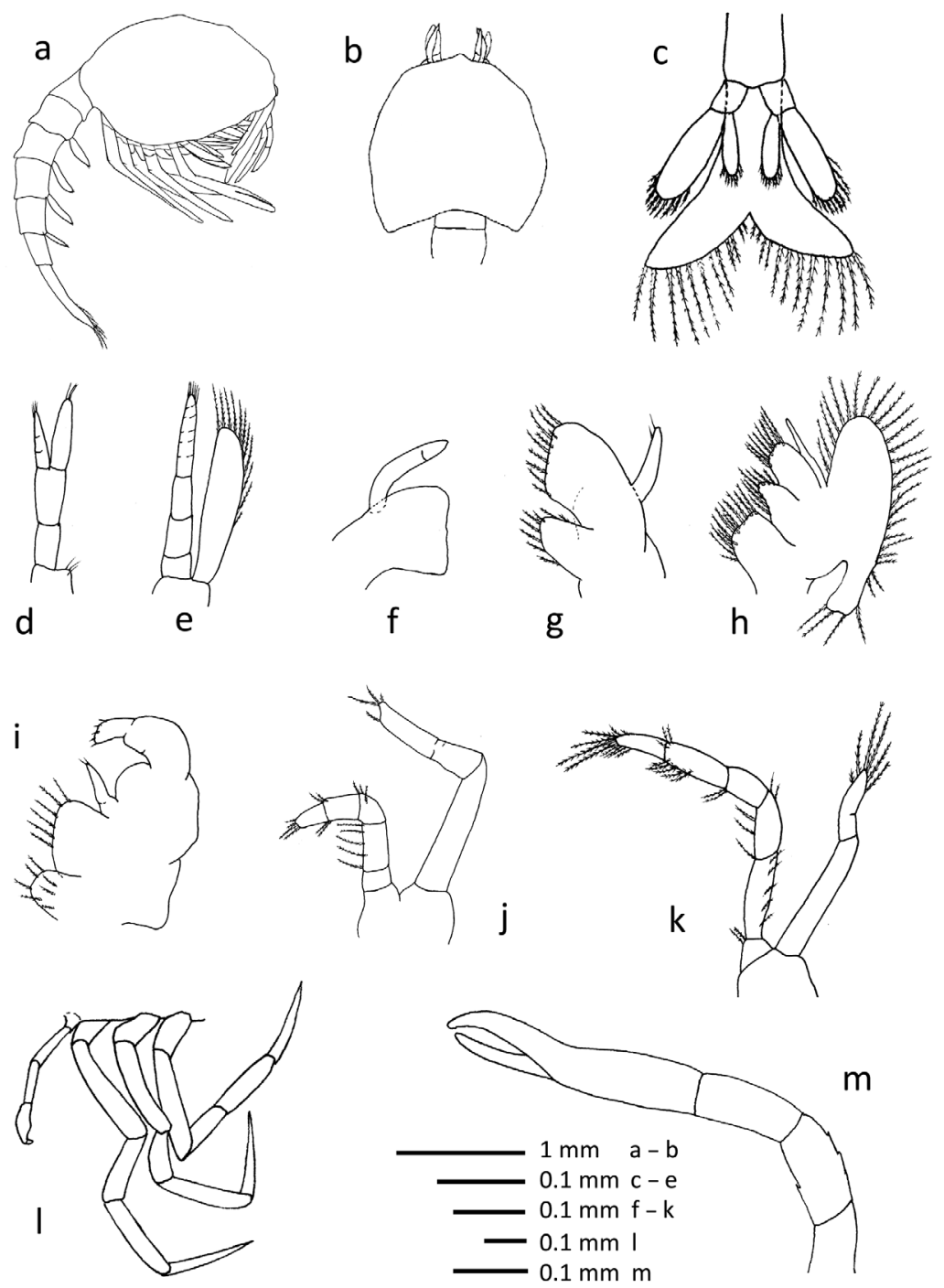

Fig. 1. Kiwa tyleri, first zoeal stage. (a) Schematic, lateral view; (b) carapace, dorsal view; (c) telson with uropods, ventral view; (d) antennule; (e) antenna; (f) mandible; (g) maxillule; (h) maxilla; (i) first maxilliped; (j) second maxilliped $_{i}(\mathrm{k})$ third maxilliped ${ }_{i}(\mathrm{l})$ second to fourth pereopod $_{i}(\mathrm{~m})$ first pereopod. Scale bars as indicated

\section{Statistical analysis}

General linear model analysis of variance testing the differences between larvae from each female for each biomass parameter analysed (DW, C, N, C:N) was applied (Sokal \& Rohlf 1995). Where average values with error estimates are given in the text or in figures and tables, these represent arithmetic means $\pm \mathrm{SD}$.

\section{RESULTS}

\section{Sampling of ovigerous females}

Ovigerous females retrieved were found showing unusually (yellowbrown) dark carapace colour (see Marsh et al. 2015), indicating hydrothermal deposition on the exoskeleton. Specimens also showed black spots or areas along carapace margins and on leg segments, indicative of necrosis. Brooded embryos were found in late stage of development.

\section{Description of megalopa stage of Kiwa tyleri}

Larvae of $K$. tyleri hatch as morphologically advanced zoeae, which are described as follows. The first zoeae (Fig. $1 \mathrm{a}-\mathrm{m} ; \mathrm{n}=10$ ) have a carapace length of 1.25 to $1.3 \mathrm{~mm}$, measured from the base of the rostrum to the postero-lateral margin of the carapace. The cephalothorax, in dorsal view, is rounded, about as long as it is wide, with a concave posterior margin, smooth, and no spines present; the postero-lateral margin of the carapace slightly expands beyond the posterior margin; cardiac, gastric and branchial regions are not differentiated; and a large volume of yolk is visible, covering the entire gastric area.

The rostrum is present as a short bud (Fig. 1b). No functional eyes are evident; eyestalks are reduced to simple buds, with no eye placodes present.

The antennule (Fig. 1d) is biramous, consists of a 3-segmented basal peduncle, an exopodite and an endopodite; 

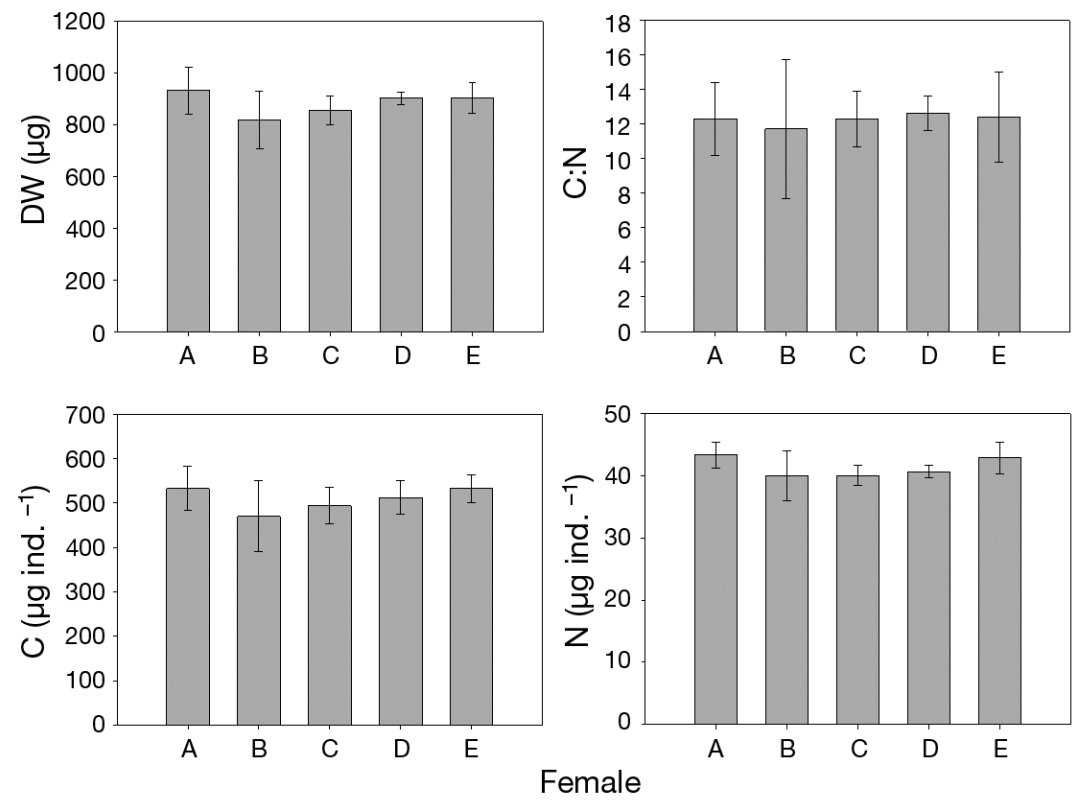

Fig. 2. Dry weight (DW), contents of carbon (C) and nitrogen (N) (all in $\mu g$ ind. ${ }^{-1}$ and in $\%$ of DW), and C:N mass ratio of first zoeal stage of Kiwa tyleri, from different females at hatching; $\mathrm{n}=5$ replicates per female, 1 individual per replicate

both endopodite and exopodite bear few short plumose setae. The proximal segment of the antennule with exopodite is incompletely divided into 3 segments. Antenna (Fig. 1e) has an endopodite and exopodite: the endopodite is extended and has many segments; the final segment is fringed with short setae; the exopodite (scaphocerite) is flat, with rounded margins, and wide, fringed with long plumose setae.

The palp of the mandible is simple and unsegmented, and the mandible has no distinct teeth or spines (Fig. 1f). The maxillule (Fig. 1g) has coxal and basial endites bearing diffusely arranged, short, plumose setae; the endopodite is unsegmented, with few minute terminal setae. The maxilla (Fig. 1h) has coxal and basial endites with plumose setae; the endopodite is sharply pointed and without setae. The exopodite (scaphognathite) is fringed with long plumose setae.

The first maxilliped (Fig. 1i) with coxa and basis well flattened, bearing few marginal, plumose setae. The unsegmented endopodite bears 2 small, short setae, and the exopodite, which appears incompletely segmented, bears few short terminal setae. The second maxilliped (Fig. 1j) endopodite has fully divided segments, bears few setae and several small spines. The 2 -segmented exopodite bears few ( 3 to 4 ) short, setose terminal setae. The third maxilliped
(Fig. 1k) is more developed than others; the endopodite is almost twice as long as the exopodite, bearing numerous plumose setae on segments, including the distal segment with terminal plumose setae. The endopodite has 4 segments, bearing setose setae. The exopodite has 2 segments, and bears 6 to 7 setose terminal setae.

Pereopods are fully developed (Fig. 11,m); pereopod 1 bears welldeveloped chela, squat-lobster like; 3 pairs of walking legs (pereopods 2 to 4) are fully articulated, segmented and without major spines. Pereopod 5 is smaller, about half as long as pereopods 2 to 4 (Fig. 11); propodus and dactylus are laterally flattened and expanded in surface; segmentation is at least partially visible.

Pairs of well-developed pleopods are present on abdominal segments 2 to 5 (Fig. 1a). Each consists of a protopod, with a short, bluntly pointed endopod and a short, bluntly pointed exopod. The tail fan is strongly bifurcate with rounded posterior margins (Fig. 1c), bearing 12+12 feathered setae; innermost pairs are very short in length; uropods are present; exopod is about $2 / 3$ as long as the telson; endopod is shorter than exopod; uropods are fringed with short, plumose setae.

The abdomen (Fig. 1a,c) consists of 6 fully segmented somites and the telson. Somites are smooth, without spines, and dorsally overlap; somites are overall simple in morphology.

A comparison of the elemental composition of larvae at hatching from 5 different females presents no statistical difference for any biomass parameter analysed (Tables $1 \& 2$ ). Larvae are large, with a DW of 855-931 $\mu \mathrm{g}$ ind. $^{-1}$. The C:N ratio is exceptionally high $(11.7-12.6)$, which is indicative of high lipid storage of maternal origin (Table 1, Fig. 2).

\section{DISCUSSION}

\section{Larval morphology and potential relatedness}

Kiwa tyleri hatches as a morphologically advanced zoea, indicating a strongly abbreviated larval development. The advanced zoeal stage shows an intermediate morphology between zeoa and megalopa: the larva already has many morphological 
Table 1. Dry weight (DW), contents of carbon (C) and nitrogen (N) (all in $\mu g$ ind. ${ }^{-1}$ and in \% of DW), and C:N mass ratio of first zoeal stage of Kiwa tyleri, from different females at hatching. Values are mean \pm SD and are based on 5 replicates per female, 1 individual per replicate

\begin{tabular}{|c|c|c|c|c|c|c|}
\hline \multirow{2}{*}{$\begin{array}{l}\text { Fe- } \\
\text { male }\end{array}$} & \multirow{2}{*}{$\begin{array}{c}\text { DW } \\
\mu \mathrm{g} \text { ind. }^{-1}\end{array}$} & \multicolumn{2}{|c|}{$-\mathrm{C}-$} & \multicolumn{2}{|c|}{$-\mathrm{N}-$} & \multirow{2}{*}{$\begin{array}{l}\mathrm{C}: \mathrm{N} \text { mass } \\
\quad \text { ratio }\end{array}$} \\
\hline & & $\mu \mathrm{g}$ ind..$^{-1}$ & $\%$ DW & $\mu g$ ind..$^{-1}$ & $\%$ DW & \\
\hline $\mathrm{A}$ & $931.2 \pm 91.8$ & $532.5 \pm 50.4$ & $57.2 \pm 1.2$ & $43.3 \pm 2.1$ & $4.7 \pm 0.4$ & $12.3 \pm 0.9$ \\
\hline $\mathrm{B}$ & $817.4 \pm 111.8$ & $469.7 \pm 79.9$ & $57.2 \pm 2.1$ & $40.0 \pm 4.0$ & $4.9 \pm 0.2$ & $11.7 \pm 0.9$ \\
\hline $\mathrm{C}$ & $855.0 \pm 56.2$ & $493.8 \pm 41.3$ & $57.7 \pm 2.1$ & $40.0 \pm 1.6$ & $4.7 \pm 0.3$ & $12.3 \pm 0.9$ \\
\hline D & $901.4 \pm 23.6$ & $512.1 \pm 37.8$ & $56.8 \pm 3.3$ & $40.6 \pm 1.0$ & $4.5 \pm 0.1$ & $12.6 \pm 0.9$ \\
\hline $\mathrm{E}$ & $904.0 \pm 59.3$ & $532.6 \pm 31.5$ & $59.0 \pm 1.5$ & $42.8 \pm 2.6$ & $4.7 \pm 0.2$ & $12.4 \pm 0.4$ \\
\hline
\end{tabular}

\section{Levels of larval endotrophy}

Food-independent larval developmental stages appear rare in the marine brachyuran and anomuran crabs, with the exception of a small number of families. There are few examples of abbreviated larval development known in marine anomuran and brachyuran crabs (Wear 1967, Pike \& Wear 1969, Tan et al. 1986, Bolaños et al.

Table 2. General linear model analysis of variance testing the differences between female Kiwa tyleri first zoeal larvae for each biomass parameter analysed ( $F$-statistic, degrees of freedom, $\mathrm{n}=$ number of replicates)

\begin{tabular}{|lcc|}
\hline Biomass parameter & $F(4, \mathrm{n}=24)$ & $\mathrm{p}$ \\
\hline Dry weight & 1.82 & 0.165 \\
Carbon (C) & 1.38 & 0.275 \\
Nitrogen (N) & 2.06 & 0.124 \\
C:N ratio & 0.93 & 0.468 \\
\hline
\end{tabular}

features typical of squat lobster megalopae, such as the fully segmented pereopods and developed chelae, and fully segmented uropods (Fig. 1). However, the segmented pereopds do not appear functional, as would be typical of a megalopa (Baba et al. 2011). Further, the abdomen still resembles typical larval length and functionality, and in general terms lacks structural reduction in somite length and shape typical of known anomuran megalopa/ juvenile stages (Baba et al. 2011, and references therein). The bifurcate tail fan places the Kiwaidae closer to the megalopa in the Galatheidae than the Chirostylidae (for discussion, see Baba et al. 2011). On the other hand, the advanced first zoea of $K$. tyleri does not have any anomuran hair on the telson, which would place it closer to the Chirostylidae than the Galatheidae (Pike \& Wear 1969, Clark \& $\mathrm{Ng}$ 2008, Baba et al. 2011). It should be noted, however, that the more advanced zoeal stages of the Chirostylidae have only been described for Chirostylus stellaris (Fujita \& Clark 2010). Knowledge of the morphology of advanced chirostylid larvae could present further taxonomic clues to the relatedness with Kiwaidae, in particular with regard to the development of the tail fan in more advanced stages. Further systematic conclusions based on the single described stage here appear premature.
2004, Calado et al. 2006). However, lecithotrophic (endotrophic) zoeal stages have so far only been recognised (or tested) in a few species, e.g. the dromiid crab Cryptodromia pileifera (Tan et al. 1986) and the pinnotherid crab Tunicotheres moseri (Bolaños et al. 2004). In the marine Anomura, more examples of lecithotrophy have been reported. There appears to be a striking preference for fully lecithotrophic larval development in the Lithodidae (king crabs), in particular in cold-water and deep-sea lineages of the group (Hall \& Thatje 2009). Furthermore, there is evidence that larval lecithotrophy may also be more common in some species of deep-sea Munidopsidae of the genus Munidopsis (Wilkens et al. 1990, Van Dover \& Williams 1991). The anomuran squat lobster $K$. tyleri belongs to the family Kiwaidae within the superfamily Chirostyloidea (for discussion, see also Schnabel \& Ahyong 2011, Roterman et al. 2013). Of the sister family Chirostylidae, the tropical and shallow-water Chirostylus ortmanni possesses a lecithotrophic and morphologically advanced first zoeal stage (Clark \& Ng 2008). Despite the evidence presented appearing compelling, the authors attributed food independence to primitive feeding structures alone, rather than biochemical proof of energy reserves. C. stellaris, which follows a strongly abbreviated larval development of 2 zoeal stages and a megalopa stage, has also been demonstrated to be lecithotrophic in both zoeal stages at least (Fujita \& Clark 2010).

The level of lecithotrophy observed in the first zoeal stage of $K$. tyleri is striking; with a $\mathrm{C}: \mathrm{N}$ ratio $\geq 11.7$, the level of lipid storage is exceptionally high, and higher than the $C: N$ ratio $(\geq 10.5)$ found in the lithodid Paralomis spinosissima from South Georgia waters, which held the previous lecithotrophy record in the Anomura (Thatje \& Mestre 2010). In lithodid crabs, lecithotrophy is common and is associated with abbreviated larval development passing through 2 or 3 zoeal stages and a megalopa stage in 
Paralomis and Lithodes, respectively (e.g. Anger et al. 2003, Watts et al. 2006). Food independence and associated reduction in activity (little to no swimming), and demersal life of larvae have frequently been used as ecological features explaining the success of this group in cold waters, in particular in the Southern Ocean (for discussion, compare Lovrich 1999, Thatje et al. 2005, Hall \& Thatje 2011). Further, subtle but significant differences in the level of lecithotrophy have been identified among other species, indicating variations in the length of food independence as well as metabolic efficiency (Kattner et al. 2003, Saborowski et al. 2006, Thatje \& Mestre 2010). The high level of lecithotrophy found in $K$. tyleri, and the lack of the zoeal stages typical of lecithotrophic larval development in the Lithodidae, may therefore indicate lecithotrophy continuing into juvenile stage(s). Indeed, in $P$. spinosissima from South Georgia waters, lecithotrophic development was found to exceed 14 mo in duration and under artificially high temperature conditions $\left(5^{\circ} \mathrm{C}\right)$ experienced in laboratory cultures (Thatje \& Mestre 2010). The level of lecithotrophy found in $K$. tyleri larvae developing in Southern Ocean temperatures ( -1.3 to $0.5^{\circ} \mathrm{C}$ ) should allow for food-independent development well beyond a year in duration. We suggest that this supports the hypothesis that the complete larval development, if not an early juvenile stage, may continue to benefit from nutrition of maternal origin and be independent of external food supply (for discussion, see Thatje \& Mestre 2010). Furthermore, abbreviated larval development does not only reduce overall larval mortality, which is highest during moult, but also minimises energy loss through cast exuviae (e.g. Calcagno et al. 2003).

\section{Physiological constraints on development and dispersal}

The impoverished Southern Ocean decapod fauna has often been explained by ecological and physiological constraints on species' life histories (for discussion, see Frederich et al. 2001, Thatje et al. 2003, Wittmann et al. 2011). K. tyleri is, to a large extent, independent of the physiological constraints of low temperature because of the optimisation of its adult life cycle to the warm-stenothermal temperature regime of vent chimneys, including chemosynthetic nutrition (see Marsh et al. 2012, 2015, Rogers et al. 2012, Reid et al. 2013; for a characterisation of epibiontic bacteria, see Zwirglmaier et al. 2014). Females leave vents to brood their young and, given the necrotic state of the carapace, may well spend the full period of embryogenesis away (Marsh et al. 2015; for a discussion of necrosis in relation to long intermoult periods at polar temperatures, see Otto \& Macintosh 1996, Reid et al. 2007). The reasons for this remain unknown, but may relate to the highly unstable thermal and chemical conditions prevailing at vent chimneys, with regard to steep chemical and thermal gradients (Fisher et al. 1988, Desbruyeres et al. 2001, Luther et al. 2001), which may negatively affect embryogenesis. Given low female fecundity (maximum N = 175 and $\mathrm{N}=207$ developing embryos, at E2 and E9, respectively; Marsh et al. 2015) and the high maternal investment into offspring demonstrated here, optimising reproductive success appears key to the species' ecology. Larval and early juvenile lecithotrophy, as discussed earlier, enables the species to employ a hypometabolic developmental mode of life whilst off the vent site. While this would result in reduced activity, it would enhance the likelihood for survival at cold polar temperatures, minimising physiological disturbance to development (for discussion, see Frederich et al. 2001, Thatje et al. 2005, Wittmann et al. 2011). Reduced mobility would require larvae and juveniles to stay in close vicinity of the vents, in order to allow for successful recruitment into the chemosynthetic vent habitat.

The geological environment surrounding the E2 and E9 vent fields (Rogers et al. 2012) is characterised by pillow and sheet lava flows of large geographic scale, which are extremely heterogeneous in topography and include uncounted crevices (for images, see Rogers et al. 2012, Marsh et al. 2012, 2015). Given this topography, we regard it as unlikely that demersal larvae, constrained in their swimming activity by the physiological effect of low temperature (Frederich et al. 2001), achieve a demersal drift state necessary for long-distance dispersal. Interestingly, larvae did not demonstrate any level of buoyancy whilst in laboratory culture nor any sustained swimming behaviour.

Consequently, we suggest that local retention of larvae and juveniles is likely and may ensure high recruitment rates into Southern Ocean vent habitats. The exceptionally high abundances of $K$. tyleri found, reaching 700 ind. $\mathrm{m}^{-2}$ at both study sites (Marsh et al. 2012), may support this idea. With an entirely chemosynthetic base to its adult life cycle (Zwirglmaier et al. 2014), local retention of all life stages may be key to the success of the species in the cold Southern Ocean environment, which has otherwise proven unfavourable to the survival of most reptant decapods (for review of Southern Ocean evolutionary history, see Aronson et al. 2007). 
Within the scenario presented here, gene flow among populations would depend on short distances between vents, relying on periods of high and sustained tectonic activity along the ESR system. Whether or not distant Kiwa populations situated on the ESR are a relict of past - or reflect current - connectivity among populations, must remain subject to future study of the genetic diversity of populations.

Acknowledgements. We thank the captain and crew of RRS 'James Cook' for assistance at sea during expedition JC42. We also thank Alex Rogers (PSO) and all participating scientists on JC42. Special thanks go to the National Environment Research Council (NERC) ROV-team for superbly running 'Isis'. Thanks also to Shir Akbari for supervising elemental analysis. This research was supported by a NERC Consortium Grant (NE/DO1249X/1; ChEsSo), and a grant from the Total Foundation (Abyss2100) to S.T.

\section{LITERATURE CITED}

Anger K, Harms J (1990) Elemental (CHN) and proximate biochemical composition of decapod crustacean larvae. Comp Biochem Physiol B Comp Biochem 97:69-80

Anger K, Thatje S, Lovrich G, Calcagno J (2003) Larval and early juvenile development of Paralomis granulosa reared at different temperatures: tolerance of cold and food limitation in a lithodid crab from high latitudes. Mar Ecol Prog Ser 253:243-251

Aronson RB, Thatje S, Clarke A, Peck LS, Blake DB, Wilga CD, Seibel BA (2007) Climate change and invasibility of the Antarctic benthos. Annu Rev Ecol Evol Syst 38: 129-154

Baba K, Fujita Y, Wehrtmann IS (2011) Developmental biology of squat lobsters. In: Poore GCB, Ahyong ST, Taylor J (eds) The biology of squat lobsters CSIRO Publishing, New York, NY, p 105-148

Bolaños J, Cuesta JA, Hernández G, Hernández J, Felder DL (2004) Abbreviated larval development of Tunicotheres moseri (Rathbun, 1918) (Decapoda: Pinnotheridae), a rare case of parental care among brachyuran crabs. Sci Mar 68:373-384

Calado R, Nogueira N, dos Santos A (2006) Extended parental care in a hermit crab of the genus Calcinus (Anomura: Diogenidae). J Mar Biol Assoc UK 86:121-123

Calcagno JA, Thatje S, Anger K, Lovrich GA, Kaffenberger A (2003) Changes in biomass and chemical composition during lecithotrophic larval development of the southern stone crab Paralomis granulosa. Mar Ecol Prog Ser 257: 189-196

Clark PF, Ng PKL (2008) The lecithotrophic zoea of Chirostylus ortmanni Miyake \& Baba, 1968 (Crustacea: Anomura: Galatheoidea) described from laboratory hatched material. Raffles Bull Zool 56:85-94

Clarke A (1990) Temperature and evolution: Southern Ocean cooling and the Antarctic marine fauna. In: Kerry KR, Hempel G (eds) Antarctic ecosystems. Ecological change and conservation. Springer-Verlag, Berlin, p 9-22

Clarke A (1993) Temperature and extinction in the sea: a physiologist's view. Paleobiology 19:499-518

Clarke A, Johnston NM (2003) Antarctic marine benthic diversity. Oceanogr Mar Biol Annu Rev 41:47-114

$>$ Crame JA (1999) An evolutionary perspective on marine faunal connections between southernmost South America and Antarctica. Sci Mar 63:1-14

> Desbruyeres D, Biscoito M, Caprais JC, Colaco A and others (2001) Variations in deep-sea hydrothermal vent communities on the Mid-Atlantic Ridge near the Azores plateau. Deep-Sea Res I 48:1325-1346

> Fisher CR, Childress JJ, Arp AJ, Brooks JM and others (1988) Microhabitat variation in the hydrothermal vent mussel, Bathymodiolus thermophilus, at the Rose Garden vent on the Galapagos Rift. Deep-Sea Res A 35: 1769-1791

Frederich M, Sartoris FJ, Pörtner HO (2001) Distribution patterns of decapod crustaceans in polar areas: a result of magnesium regulation? Polar Biol 24:719-723

Fujita Y, Clark PF (2010) The larval development of Chirostylus stellaris Osawa, 2007 (Decapoda: Anomura: Chirostylidae) described from laboratory-reared material. Crustac Res 39:53-64

Gorny M (1999) On the biogeography and ecology of the Southern Ocean decapod fauna. Sci Mar 63:367-382

> Hall S, Thatje S (2009) Global bottlenecks in the distribution of marine Crustacea: temperature constraints in the family Lithodidae. J Biogeogr 36:2125-2135

Hall S, Thatje S (2011) Temperature driven biogeography of the family Lithodidae (Decapoda: Crustacea) in the Southern Ocean. Polar Biol 34:363-370

Kattner G, Graeve M, Calcagno JA, Lovrich GA, Thatje S, Anger K (2003) Lipid, fatty acid and protein utilization during lecithotrophic larval development of Lithodes santolla (Molina) and Paralomis granulosa (Jacquinot). J Exp Mar Biol Ecol 292:61-74

Lovrich GA (1999) Seasonality of larvae of Brachyura and Anomura (Crustacea Decapoda) in the Beagle Channel, Argentina. Sci Mar 63:347-354

> Luther GW III, Rozan TF, Taillefert M, Nuzzio DB and others (2001) Chemical speciation drives hydrothermal vent ecology. Nature 410:813-816

Macpherson E, Jones W, Segonzac M (2005) A new squat lobster family of Galatheoidea (Crustacea, Decapoda, Anomura) from the hydrothermal vents of the PacificAntarctic Ridge. Zoosystema 27:709-723

Marsh L, Copley JT, Huvenne VAI, Linse K and others (2012) Microdistribution of faunal assemblages at deepsea hydrothermal vents in the Southern Ocean. PLoS ONE 7:e48348

Marsh L, Copley JT, Tyler PA, Thatje S (2015) In hot and cold water: differential life-history adaptations are key to success in contrasting thermal deep-sea environments. J Anim Ecol, doi:10.1111/1365-2656.12337

Otto RS, Macintosh RA (1996) Observations on the biology of the lithodid crab Paralomis spinosissima from the Southern Ocean near South Georgia. In: Otto RS, Macintosh RA (eds) High latitude crabs: biology, management and economics. Alaska Sea Grant College Prog Rep No 96-02. University of Alaska, Fairbanks, AK, p 627-647

Pike RB, Wear RG (1969) Newly hatched larvae of the genera Gastroptychus and Uroptychus (Crustacea, Decapoda, Galatheidea) from New Zealand waters. Trans R Soc N Z 11:189-195

- Ravaux J, Gaill F, Le Bris N, Sarradin PM, Jollivet DB, Shillito B (2003) Heat-shock response and temperature resistance in the deep-sea vent shrimp Rimicaris exoculata. J Exp Biol 206:2345-2354 
Reid W, Watts J, Clarke S, Belchier M, Thatje S (2007) Egg development, hatching rhythm and moult patterns in reared Paralomis spinosissima (Decapoda: Anomura: Paguroidea: Lithodidae) from South Georgia waters (Southern Ocean). Polar Biol 30:1213-1218

Reid WDK, Sweeting CJ, Wigham BD, Zwirglmaier K and others (2013) Spatial differences in East Scotia Ridge hydrothermal vent food webs: influences of chemistry, microbiology and predation on trophodynamics. PLoS ONE 8:e65553

Rogers AD, Tyler PA, Connelly DP, Copley JT and others (2012) The discovery of new deep-sea hydrothermal vent communities in the Southern Ocean and implications for biogeography. PLoS Biol 10:e1001234

Roterman CN, Copley JT, Linse KT, Tyler PA, Rogers AD (2013) The biogeography of the yeti crabs (Kiwaidae) with notes on the phylogeny of the Chirostyloidea (Decapoda: Anomura). Proc R Soc Lond B Biol Sci 280:20130718

Saborowski R, Thatje S, Calcagno JA, Lovrich GA, Anger K (2006) Digestive enzymes in the ontogenetic stages of the southern king crab, Lithodes santolla. Mar Biol 149: 865-873

Schnabel KE, Ahyong ST (2011) A new classification of the Chirostyloidea (Crustacea: Decapoda: Anomura). Zootaxa 2687:56-64

Shevenell AE, Kennett JP, Lea DW (2004) Middle Miocene Southern Ocean cooling and Antarctic cryosphere expansion. Science 305:1766-1770

Smith CR, Grange LJ, Honig DL, Naudts L, Huber B, Guidi L, Domack E (2012) A large population of king crabs in Palmer Deep on the west Antarctic Peninsula shelf and potential invasive impacts. Proc R Soc Lond B Biol Sci 279:1017-1026

Sokal RR, Rohlf FJ (1995) Biometry: the principles and practices of statistics in biological research. Freeman, New York, NY

Tan LWH, Lim SSL, Ng PKL (1986) The complete larval development of the dromiid crab, Cryptodromia pileifera Alcock, 1899 (Decapoda: Dromiidae) in the laboratory. J Crustac Biol 6:111-118

Thatje S (2012) Effects of capability for dispersal on the evolution of diversity in Antarctic benthos. Integr Comp Biol 52:470-482

Thatje S, Arntz WE (2004) Antarctic reptant decapods: more than a myth? Polar Biol 27:195-201

Thatje S, Mestre NC (2010) Energetic changes throughout lecithotrophic larval development in the deep-sea lithodid crab Paralomis spinosissima from the Southern Ocean. J Exp Mar Biol Ecol 386:119-124

Thatje S, Schnack-Schiel S, Arntz WE (2003) Developmental trade-offs in Subantarctic meroplankton communities

Editorial responsibility: Antonio Baeza,

Fort Pierce, Florida, USA and the enigma of low decapod diversity in high southern latitudes. Mar Ecol Prog Ser 260:195-207

- Thatje S, Anger K, Calcagno JA, Lovrich GA, Pörtner HO, Arntz WE (2005) Challenging the cold: crabs reconquer the Antarctic. Ecology 86:619-625

Thatje S, Hall S, Hauton C, Held C, Tyler PA (2008) Encounter of lithodid crab Paralomis birsteini on the continental slope off Antarctica, sampled by ROV. Polar Biol 31:1143-1148

Thatje S, Marsh L, Roterman CN, Mavrogordato MN, Linse $\mathrm{K}$ (2015) Adaptations to hydrothermal vent life in Kiwa tyleri, a new species of Yeti Crab from the East Scotia Ridge, Antarctica. PLoS ONE, doi:10.1371/journal.pone. 0127621

Thurber AR, Jones WJ, Schnabel K (2011) Dancing for food in the deep sea: bacterial farming by a new species of yeti crab. PLoS ONE 6:e26243

Tokeshi M (2011) Spatial structures of hydrothermal vents and vent-associated megafauna in the back-arc basin system of the Okinawa Trough, western Pacific. J Oceanogr 67:651-665

Van Dover CL, Williams AB (1991) Egg size in squat lobsters (Galatheoidea): constraint and freedom. Crustac Issues 7:143-156

> Watts J, Thatje S, Clarke S, Belchier M (2006) A description of larval and early juvenile development in Paralomis spinosissima (Decapoda: Anomura: Paguroidea: Lithodidae) from South Georgia waters (Southern Ocean). Polar Biol 29:1028-1038

Wear RG (1967) Life-history studies of New Zealand Brachyura. I. Embryonic and postembryonic development of Pilumnus novaezealandiae Filhol, 1886, and of $P$. lumpinus Bennett, 1964 (Xanthidae, Piluminae). N Z J Mar Freshw Res 1:482-535

Wilkens H, Parzefall J, Ribowski A (1990) Population biology and larvae of the anchialian crab Munidopsis polymorpha (Galatheidae) from Lanzarote (Canary Islands). J Crustac Biol 10:667-675

Wittmann AC, Storch D, Anger K, Pörtner HO, Sartoris FJ (2011) Temperature-dependent activity in early life stages of the stone crab Paralomis granulosa. J Exp Mar Biol Ecol 397:27-37

- Zachos J, Pagani M, Sloan L, Thomas E, Billups K (2001) Trends, rhythms, and aberrations in global climate $65 \mathrm{Ma}$ to present. Science 292:686-693

Zwirglmaier K, Reid WDK, Heywood J, Sweeting CJ and others (2014) Linking regional variation of epibiotic bacterial diversity and trophic ecology in a new species of Kiwaidae (Decapoda, Anomura) from East Scotia Ridge (Antarctica) hydrothermal vents. MicrobiologyOpen 4: $136-150$

Submitted: October 17, 2013; Accepted: January 15, 2015

Proofs received from author(s): February 27, 2015 